\title{
PAJAK PENGHASILAN PADA UMKM SEKTOR PERDAGANGAN
}

\author{
Restiyanti ${ }^{1)}$ \\ Ari Budi Kristanto ${ }^{2)}$ \\ 1) Fakultas Ekonomika dan Bisnis, Universitas Kristen Satya Wacana Salatiga \\ e-mail:232010089@student.uksw.edu \\ 2) Fakultas Ekonomika dan Bisnis, Universitas Kristen Satya Wacana Salatiga \\ e-mail: ari.kristanto@staff.uksw.edu
}

\begin{abstract}
The research aimed to compare the calculation method of income tax using methods of "pembukuan" and "pencatatan" based on the income tax law (UU PPh) No. 36 year 2008, as well as the calculation method according to the government regulation (PP) No. 46 year 2013, regarding the trade sector of MSMEs. The research data was obtained from questionnaires and interviews directly sent to the owners of the trade sector MSMEs in Kecamatan Tengaran. The sampling method of this research is snowball sampling technique. The tax payable that have been calculated by the respondents were compared to respondents' nature of the business, commodity type, and business size. The result of this study showed that the tax calculation based on government regulation (PP) No. 46 year 2013 was the method that lead to the most efficient tax payable for the trading business for both retail and distributor for clothing, vegetables and daily needs trading business; and also for small scale trading business. However for micro scale trading businesses, the method of "Pencatatan" was the most efficient method for these respondents group. The research concluded that there was no single method providing results as the most efficient tax payable for all group of respondents. Based on this finding, it can be recommended to the regulator to make the income tax calculation method is as an option instead of rigid regulation, as the background of the regulation is the simplicity to the tax payer (particularly on Government Regulation (PP) No 46 year2013) and in order to achieve the principle of taxation, namely the principle of economic efficiency.
\end{abstract}

Keywords: Micro Small and Medium Enterprises, trade sector, tax income, tax calculation

\section{PENDAHULUAN}

Pada tanggal 1 Juli 2013 pemerintah memberlakukan Peraturan Pemerintah (PP) No 46 tahun 2013, yaitu pungutan pajak sebesar 1\% dari peredaran bruto, bagi pengusaha dengan peredaran usaha sampai dengan Rp.4,8 milyar per tahun terhadap Wajib Pajak Badan maupun Orang Pribadi. Sebelumnya pajak penghasilan bagi kategori pengusaha tersebut (termasuk didalamnya UMKM), dilaksanakan berdasarkan Undang-Undang No. 36 tahun 2008 dengan dua alternatif metode penghitungan yaitu: pembukuan dan pencatatan. Tarif pajak penghasilan yang diatur dalam PP No. 46 tahun 2013 adalah 1\% dari peredaran bruto yang dibayarkan setiap bulan, dan pajak yang dikenakan termasuk ke dalam jenis pajak final. Seperti yang dikatakan Mustadir dalam acara sosialisasi perpajakan (www.pajak.co.id) "Sederhana dan mudah! Itulah nafas utama dari PP No. 46 Tahun 2013”.

Pemerintah mulai melirik sektor usaha yang memiliki potensi besar untuk pemasukan pajak, yaitu dari Usaha Mikro Kecil Menengah (UMKM). UMKM pada umumnya memiliki peredaran bruto dan laba yang jauh lebih kecil dibandingkan dengan perusahaan-perusahaan 
besar. Namun keberadaan usaha ini bisa dikatakan memberikan sumbangsih yang berarti bagi pertumbuhan ekonomi (Resyniar, 2013).

Tabel 1. Perkembangan PDB UMKM dan Usaha Besar Tahun 2009-2011

\begin{tabular}{lrrrr}
\hline \multirow{2}{*}{ Jenis Usaha } & \multicolumn{2}{c}{ PDB atas harga (Miliar Rupiah) } & \multirow{2}{*}{ Rata-rata } \\
\cline { 2 - 4 } & \multicolumn{1}{c}{$\mathbf{2 0 0 9}$} & \multicolumn{1}{c}{$\mathbf{2 0 1 0}$} & \multicolumn{1}{c}{$\mathbf{2 0 1 1}$} & \\
\hline Usaha Mikro & $1.751 .644,60$ & $2.051 .878,60$ & $2.579 .388,40$ & $2.127 .637,20$ \\
Usaha Kecil & $528.244,20$ & $597.770,20$ & $722.012,80$ & $616.009,07$ \\
Usaha Menengah & $713.262,90$ & $816.745,10$ & $1.002 .170,30$ & $844.059,43$ \\
Usaha Besar & $2.301 .709,20$ & $2.602 .369,50$ & $3.123 .514,60$ & $2.675 .864,43$ \\
Total & $5.294 .860,90$ & $6.068 .763,40$ & $7.427 .086,10$ & $6.263 .570,13$ \\
\hline
\end{tabular}

Sumber: data Kementerian Koperasi dan UKM

Tabel 1 menunjukkan besarnya kontribusi UMKM dalam Produk Domestik Bruto (PDB), yang jumlahnya melebihi usaha besar. Jumlah rata-rata PDB yang dihasilkan UMKM berjumlah Rp.3.587.705,50 miliar sedangkan rata-rata PDB atas Usaha Besar berjumlah 2.675.864,43 miliar. Menurut Herman dan Nurul (2013) peranan UMKM cukup besar dalam menciptakan PDB di Indonesia yang apabila dikelola dengan baik akan memiliki kontribusi ke negara berupa pajak.

Menurut penelitian Jacklyn dan Sirajuddin (2013) tentang persepsi Wajib Pajak Badan dan Orang Pribadi yang terdaftar di KPP Madya Palembang, ditemukan adanya pro dan kontra atas Peraturan Pemerintah No. 46 Tahun 2013. Wajib Pajak Orang Pribadi belum mendapat penyuluhan mendalam mengenai PP No. 46 Tahun 2013. Penyuluhan mendalam hanya dilakukan untuk WP Badan saja, sehingga belum semua WP mengerti dan memahami PP No. 46 tahun 2013. Dari kesimpulan penelitian Jacklyn dan Sirajuddin (2013), jika bagi WP Badan yang telah memenuhi kewajiban perpajakan sesuai dengan PP No. 46 Tahun 2013 dijanjikan oleh Pemerintah akan dibantu untuk kemudahan mendapatkan kredit perbankan. Namun Wajib Pajak Orang Pribadi yang belum mendapat penyuluhan secara mendalam mengenai PP No. 46 tahun 2013 terus dikenai pajak baik saat berhasil memperoleh laba maupun pada saat menderita kerugian.

Menurut Syarif Hasan (Menkop UMKM) dalam acara FORBIS di Metro TV tanggal 22 Juli 2013 (www.youtube.com), pemberlakuan pungutan PP No 46 Tahun 2013 ini dibanding pungutan berdasarkan UU No 36 Tahun 2008 tarif pasal 17 jauh lebih rendah karena dalam tarif UU No. 36 Tahun 2008 pasal 17 dikenakan 25 persen dari penghasilan bersih, sedangkan untuk PP No 46 Tahun 2013 hanya 1 persen tarif final dari peredaran bruto per tahun. Dalam kesempatan yang sama, Chatib Basri (MENKEU), penerapan PP No. 46 Tahun 2013 diharapkan akan mendorong pertumbuhan UMKM menjadi sektor formal. Kemudahan mendapat kredit perbankan bagi sektor formal akan meningkatkan usaha pelaku UMKM.

Di sisi lain perwakilan asosiasi pengusaha dalam acara yang sama ada yang menolak PP No. 46 Tahun 2013, dinilai karena waktu pelaksanaan yang tidak tepat di mana industri sedang melakukan rebalancing atas kenaikan BBM dan menjelang bulan ramadhan. Sedangkan kelompok perwakilan asosiasi pengusaha lain dalam acara yang sama, menerima pemberlakuan PP No. 46 Tahun 2013 dengan syarat ada timbal balik dari pemerintah untuk kesejahteraan para pedagang UMKM sehingga peraturan ini dinilai dapat membina UMKM untuk lebih baik bukan membinasakan UMKM. 
Ulasan di atas menunjukkan adanya pro kontra berdasarkan pendapat pemerintah dengan perwakilan asosiasi tentang pemberlakuan PP No. 46 Tahun 2013, mengenai apakah pemberlakuan tersebut merupakan insentif ataukah disinsentif bagi pelaku UMKM. Di sisi lain, kebijakan yang diambil pemerintah (termasuk kebijakan pajak), akan lebih sejalan dengan konsep ekonomi kerakyatan apabila memberi insentif bagi usaha rakyat, termasuk UMKM.

Penelitian ini merupakan replikasi dari penelitian sebelumnya yang dilakukan oleh Adhitama (2013), dimana dalam penelitian tersebut dilakukan identifikasi alternatif perhitungan pajak yang efisien bagi pelaku UMKM dan menghitung potensi penerimaan pajak penghasilan pelaku UMKM di sentra industri kecil konveksi kecamatan Tingkir Kota Salatiga. Perhitungan potensi penerimaan pajak tersebut dilakukan dengan membandingkan jumlah pajak terutang pada pajak final 1 persen menurut Peraturan Pemerintah (PP) No. 46 Tahun 2013 dengan ketentuan menurut UU No. 36 Tahun 2008 (metode pembukuan dan metode pencatatan (norma)).

Penelitian Adhitama (2013) menyimpulkan bahwa jika PP No. 46 Tahun 2013 bersifat opsional dan tidak wajib, maka probabilitas kepatuhan WP meningkat dan kemauan wajib pajak semakin besar dalam mempelajari metode pencatatan dan pembukuan yang dalam jangka panjang dimana hal ini akan menguntungkan pemerintah ketika wajib pajak memahami metode pencatatan dan pembukuan.

Pada umumnya UKM level mikro dan kecil memiliki profit dengan rasio yang tidak signifikan antara omzet dan biayanya. Elemen biaya inilah yang belum masuk dalam pertimbangan pada PP No. 46 Tahun 2013. Untuk menciptakan sebuah peraturan yang menunjang prinsip keadilan maka perlu dimasukkan kombinasi agar elemen biaya terakomodir dalam peraturan ini sehingga tagihan pajak yang muncul mencerminkan prinsip keadilan (Adhitama, 2013).

Penelitian ini perlu dilakukan ulang karena, diduga akan ada perbedaan hasil berdasarkan prinsip pemungutan pajak yang berbeda. Penelitian ini menggunakan objek UMKM sektor perdagangan yang berlokasi di Kabupaten Semarang, khususnya di Kecamatan Tengaran. Sektor perdagangan dipilih, karena berdasarkan data BPS tahun 2013, sektor perdagangan menjadi salah satu komponen utama pembentuk struktur ekonomi Kabupaten Semarang (semarangkab. bps.go.id). Kecamatan Tengaran dipilih karena berlokasi di jalur pengembangan industri sebagai pusat-pusat pertumbuhan ekonomi dengan memanfaatkan peluang pembangunan jalan tol Semarang-Solo (Peraturan Daerah Kabupaten Semarang No. 6 Tahun 2011) sehingga Kecamatan Tengaran akan menjadi daya tarik bagi usaha perdagangan. Penelitian sebelumnya menganalisis usaha konveksi yang dilihat berdasarkan ukuran usaha. Penelitian ini meneliti bukan hanya dari ukuran usaha melainkan dari jenis komoditasnya yang diduga akan terdapat relevansi terkait dampak pengenaan tarif pajak berdasarkan PP No 46. tahun 2013 terhadap usaha tersebut.

Berdasarkan hasil survei KPJU oleh Bank Indonesia, komoditas unggulan pada sektor perdagangan kabupaten Semarang terdapat 3 jenis komoditas yang diunggulkan yakni: perdagangan eceran pakaian jadi di dalam bangunan, perdagangan eceran sayuran di dalam bangunan, dan sembako (www.bi.go.id).

Berdasarkan latar belakang di atas maka dapat dirumuskan masalah penelitian ini adalah "Manakah dari metode pembukuan dan pencatatan menurut UU No 36 Tahun 2008 atau metode menurut PP No 46 Tahun 2013 yang menghasilkan pajak terutang paling efisien bagi pelaku UMKM perdagangan di Kecamatan Tengaran”. Hasil penelitian ini dapat dimanfaatkan bagi regulator pajak sebagai bahan evaluasi kebijakan penerapan PP No 46 Tahun 2013. 


\section{KAJIAN TEORI}

\section{Pajak}

Menurut Undang-Undang Nomor 6 Tahun 1983 tentang Ketentuan Umum dan Tata Cara Perpajakan sebagaimana telah beberapa kali diubah terakhir dengan Undang-Undang Nomor 16 Tahun 2009, pajak didefinisikan sebagai kontribusi wajib kepada negara yang terutang oleh orang pribadi atau badan bersifat memaksa berdasarkan UU, dengan tidak mendapatkan kontraprestasi secara langsung dan digunakan untuk keperluan negara bagi sebesar-besarnya kemakmuran rakyat. Adapun (Prasetyono, 2011) menyatakan bahwa pajak adalah iuran rakyat kepada kas negara berdasarkan undang-undang, sebagai perwujudan pengabdian dan peran serta rakyat untuk membiayai negara dan pembangunan nasional. Barata (2011) menyatakan bahwa pajak adalah salah satu sumber penerimaan yang memberikan kontribusi cukup besar terhadap penerimaan negara.

\section{Potensi Pajak UMKM dan Masalah Pemungutan Pajak}

Jumlah UMKM yang semakin banyak dan berkembang, membuat semakin besar pula potensi penerimaan pajak dari sektor UMKM. Pajak penghasilan memberikan kontribusi besar pada potensi penerimaan pajak. Tetapi jika tidak dikelola dengan baik potensi penerimaan pajak itu bisa tidak terserap sepenuhnya bahkan hilang. Menurut data Kementerian Negara Koperasi dan Usaha Mikro, Kecil dan Menengah 2009, diperkirakan sekitar Rp1.214,73 triliun atau 58,17\% dari total Produk Domestik Bruto (PDB) berasal dari sektor UMKM. Sumbangan untuk pajak dari sektor UMKM masih sangat kecil. Menurut catatan Ditjen Pajak, sumbangan penerimaan pajak sektor UMKM hanya Rp65,012 miliar atau baru mencapai 0,54\% dari total PDB sektor UMKM (www.bapepam.go.id). Penerimaan pajak sektor UMKM pada periode Juli 2013 sampai dengan Juni 2014 baru mencapai Rp2 triliun, jauh dari potensinya sebesar Rp. 30 triliun (Bisnis.com, 2014). Angka-angka tersebut menandakan bahwa masih besarnya potensi pajak khususnya pajak penghasilan dari sektor UMKM yang masih belum digali secara maksimal.

Menurut Rustiyaningsih (2011) kendala dalam peningkatan penerimaan pajak adalah faktor kepatuhan wajib pajak dalam melaksanakan kewajiban perpajakan. Berdasarkan hasil penelitian Wirapati dan Jati (2014), faktor-faktor yang menyebabkan perilaku kepatuhan wajib pajak antara lain pemahaman, penghasilan, manfaat yang dirasakan serta sanksi pajak. Sesuai sistem pemungutan pajak di Indonesia Self Assessment System maka wajib pajaklah yang memiliki wewenang, kepercayaan dan tanggung jawab dalam hal perpajakannya. Berdasarkan data Direktorat Jendral Pajak, tingkat kepatuhan penyampaian SPT tahunan dari tahun 2002 sampai dengan tahun 2008 berkisaran pada sekitar 33 persen, dan pada periode tahun 2008 sampai 2009 meningkat menjadi 54 persen. Semenjak tahun 2008 sampai 2011 rasio kepatuhan pajak mengalami kondisi fluktuasi pada angka sekitar 52 sampai 54 (Pudjono, 2014).

Menurut Jackson dan Milliron (1986), salah satu variabel nonekonomi kunci dari perilaku kepatuhan pajak adalah dimensi keadilan pajak. Pembayar pajak cenderung untuk menghindari membayar pajak jika mereka menganggap sistem pajak tidak adil. Hal tersebut menunjukkan pentingnya dimensi keadilan pajak sebagai variabel yang mempengaruhi perilaku kepatuhan pembayar pajak. Menurut Choiruman (2004), berhubung penerimaan pajak dibutuhkan untuk membiayai penyelenggaraan pemerintahan maupun pembangunan, pemerintah akan terus berupaya menggali potensi pajak (tax coverage) seoptimal mungkin dan juga meningkatkan kepatuhan wajib pajak (taxpayers' compliance). Namun upaya tersebut akan menghadapi berbagai kendala antara lain adalah rendahnya kesadaran masyarakat (taxpayers' awareness) 
untuk membayar pajak, belum optimalnya pelaksanaan penyuluhan dan pelayanan di bidang perpajakan, dan banyak potensi pajak yang belum tergali dan terealisasi secara optimal sehingga tax rationya rendah (Kurniawan, 2004).

Pemerintah berupaya meningkatkan kepatuhan wajib pajak dengan cara-cara yang bertujuan mewujudkan kesadaran wajib pajak pada kewajiban perpajakan (Rustiyaningsih, 2011). Hal ini menjadikan kepatuhan dan kesadaran wajib pajak menjadi faktor yang sangat penting untuk mencapai keberhasilan penerimaan pajak (Arum, 2012). Untuk mendorong terserapnya potensi pajak maka peraturan pajak dalam hal ini PP No. 46 Tahun 2013 harus menjadi peraturan pajak yang adil agar kepatuhan wajib pajak meningkat serta munculnya kesadaran wajib pajak yang berimbas pada penerimaan negara. Hal ini merupakan alasan pentingnya dimensi keadilan pajak sebagai variabel yang mempengaruhi perilaku kepatuhan pembayar pajak.

\section{Metode Penghitungan Pajak Penghasilan UU No. 36 Tahun 2008}

Metode Pembukuan. Pembukuan diselenggarakan dengan prinsip taat asas dan dengan stelsel akrual atau stelsel kas. Pembukuan sekurang-kurangnya terdiri atas catatan mengenai harga, kewajiban, modal, penghasilan, dan biaya, serta penjualan dan pembelian sehingga dapat dihitung besarnya pajak yang terutang. Metode pembukuan memiliki kelebihan bagi wajib pajak yang telah mampu melaksanakan pembukuan nantinya diharapkan akan memiliki tagihan pajak yang lebih rendah dibandingkan dengan metode norma (Waluyo, 2012).

Penghitungan penghasilan neto dengan metode pembukuan adalah dengan cara mengurangkan biaya-biaya dari penghasilan bruto sehingga didapat penghasilan neto. Penghasilan neto tersebut menjadi dasar pengenaan pajak dengan terlebih dahulu dikurangkan dengan penghasilan tidak kena pajak selanjutnya pajak dihitung berdasarkan tarif berlaku.

Metode Pencatatan. Dalam keputusan Direktur Jenderal Pajak Nomor KEP-536/PJ/2000 tentang norma penghitungan penghasilan neto bagi wajib pajak yang dapat menghitung penhasilan neto dengan menggunakan norma penghitungan. Wajib Pajak Orang Pribadi (WPOP) boleh memilih untuk menggunakan Metode Pencatatan. Metode pencatatan diperuntukkan untuk WPOP dengan pendapatan dari pekerjaan bebas yang memiliki peredaran bruto paling banyak Rp4.8 miliar setahun, dimana metode pencatatan ini menggunakan norma penghitungan penghasilan neto untuk memudahkan penghitungan pajak terutang.

Penghasilan neto bagi tiap jenis usaha dihitung dengan cara mengalikan angka presentase norma penghitungan penghasilan neto dengan peredaran bruto atau penghasilan bruto dari kegiatan usaha atau pekerjaan bebas dalam 1 (satu) tahun. Dalam menghitung besarnya pajak penghasilan yang terutang oleh wajib pajak orang pribadi, sebelum dilakukan penerapan tarif umum terlebih dahulu dihitung penghasilan kena pajak dengan mengurangkan penghasilan tidak kena pajak dari penghasilan neto.

Metode Penghitungan Pajak Penghasilan Menurut Peraturan Pemerintah No. 46 Tahun 2013. PP No. 46 Tahun 2013 diterbitkan sesuai pertimbangan bahwa untuk memberikan kemudahan kepada WPOP dan Badan yang memiliki peredaran bruto tertentu, perlu memberikan perlakuan tersendiri ketentuan mengenai penghitungan, penyetoran, dan pelaporan Pajak Penghasilan yang terutang. Peraturan Pemerintah No. 46 Tahun 2013 mengubah dasar pengenaan objek pajak dari PPh Pasal 17 menjadi PPh Pasal 4 ayat 2 (final). Sesuai dengan Pasal 3 PP No. 46 
Tahun 2013, besaran tarif $\mathrm{PPh}$ final adalah sebesar 1\%, yang dikenakan dari penghasilan bruto. Syarat yang harus dipenuhi dalam pengenaan pajak PP No. 46 Tahun 2013 antara lain:

1. Wajib Pajak orang pribadi atau badan

2. Menerima penghasilan dari usaha tidak termasuk penghasilan dari jasa sehubungan dengan pekerjaan bebas, dengan peredaran bruto tidak melebihi Rp4.800.000,00 (empat miliar delapan ratus juta rupiah) dalam 1 (satu) tahun pajak.

Peraturan Pemerintah ini kemudian dilaksanakan dengan menerbitkan Peraturan Menteri Keuangan (PMK) No. 107 Tahun 2013, pada tanggal 30 Juli 2013. Pasal 3 PMK tersebut, memberikan pedoman untuk menentukan jumlah peredaran bruto, yaitu dari usaha seluruhnya termasuk dari cabang, tidak termasuk peredaran bruto dari:

1. Jasa sehubungan dengan pekerjaan bebas,

2. Penghasilan yang diterima atau diperoleh dari luar negeri,

3. Usaha yang atas penghasilannya telah dikenakan Pajak Penghasilan yang bersifat final dengan ketentuan peraturan perundang-undangan perpajakan tersendiri.

4. Penghasilan yang dikecualikan sebagai objek pajak

\section{METODE PENELITIAN}

Populasi penelitian ini yaitu pelaku Usaha Mikro, Kecil dan Menengah sektor perdagangan yang ada di Kecamatan Tengaran. Jenis data yang digunakan adalah data primer. Data primer merupakan data yang didapat dari sumber pertama, dari individu seperti hasil wawancara atau hasil pengisian kuesioner yang biasa dilakukan peneliti. Data tersebut diperoleh langsung dari pemilik usaha perdagangan mikro, kecil dan menengah yaitu data profil usaha, jumlah pendapatan, dan biaya usaha. Teknik analisis data yang digunakan yaitu teknik analisis deskriptif kuantitatif.

Teknik pengambilan sampel dilakukan dengan cara snowball sampling, yaitu metode pengambilan sampel di mana peneliti tidak banyak mengetahui berapa populasi objek penelitiannya. Peneliti menggunakan teknik snowball sampling berdasarkan penilaiannya atas satu atau dua responden yang dianggap bisa dijadikan sampel. Informasi tentang calon responden berikutnya didapat dari responden yang telah diwawancarai hingga kemudian diperoleh jumlah sampel yang sekiranya dinilai dapat mempresentasikan penelitian. Adapun yang akan menjadi sampel dalam penelitian ini adalah usaha dagang mikro, kecil dan menengah dengan jenis eceran dan distributor dengan jenis usaha perdagangan eceran pakaian jadi di dalam bangunan, perdagangan eceran sayuran di dalam bangunan, dan sembako di daerah Kabupaten Semarang khusunya di Kecamatan Tengaran.

Langkah-langkah analisis data adalah sebagai berikut.

1. Identifikasi jenis profil usaha dagang, jumlah pendapatan dan beban usaha pada UMKM perdagangan di Kecamatan Tengaran.

2. Menghitung besarnya pajak UMKM perdagangan di Kecamatan Tengaran berdasarkan UU No. 36 Tahun 2008 dengan metode pembukuan.

3. Menghitung besarnya pajak UMKM perdagangan di Kecamatan Tengaran berdasarkan UU No. 36 Tahun 2008 dengan metode pencatatan (norma).

4. Menghitung besarnya pajak UMKM perdagangan di Kecamatan Tengaran berdasarkan PP No. 46 Tahun 2013.

5. Membandingkan hasil perhitungan besarnya pajak berdasarkan ketiga alternatif penghitungan. 
6. Mengidentifikasi metode penghitungan yang menghasilkan pajak terutang paling efisien jika dilihat dari sifat usaha, jenis komoditas, dan ukuran usaha bagi UMKM sektor perdagangan yang menjadi responden.

\section{HASIL DAN PEMBAHASAN}

\section{Gambaran Umum Responden}

Peneliti melakukan wawancara dengan staff kecamatan di Kecamatan Tengaran. Kecamatan Tengaran terdiri atas 15 desa yaitu desa Barukan, Bener, Butuh, Cukil, Duren, Karangduren, Klero, Nyamat, Patemon, Regunung, Sruwen, Sugihan, Tegalrejo, Tegalwaton, dan Tengaran. Kecamatan Tengaran terdiri atas 104 dusun. Mayoritas penduduk Kecamatan Tengaran berprofesi sebagai petani dan pedagang. Keberadaan pasar sebagai sarana perekonomian di Kecamatan Tengaran sangat mempengaruhi roda kehidupan karena dari pasar mereka mendapat penghasilan. Terdapat 4 (empat) pasar induk di Kecamatan Tengaran, yaitu di Desa Klero, Tengaran, Karangduren dan Sruwen. Selain pasar, lahan persawahan yang cukup luas merupakan sumber penghasilan bagi petani.

Tabel 2. Distribusi Responden Penelitian

\begin{tabular}{lclc}
\hline \multicolumn{1}{c}{ Lokasi Responden } & Jumlah & Lokasi Responden & Jumlah \\
\hline Karangduren & 14 & Losari & 1 \\
Ngadirno & 1 & Patemon & 1 \\
Gumuk & 3 & Tengaran & 3 \\
Sruwen & 1 & Bener & 1 \\
Ngentak & 1 & Kaligandu & 1 \\
Poncol & 1 & Sendang & 1 \\
Kalikendel & 1 & & \\
\hline Total & & & 30 \\
Sumber: data olah 2014 & & &
\end{tabular}

Lokasi penyebaran kuesioner untuk pengambilan sampel hanya ada di beberapa dusun di desa Kecamatan Tengaran. Dari hasil penyebaran kuesioner, ditemukan bahwa dusun yang tidak menjadi responden merupakan dusun dengan mayoritas penduduknya berprofesi sebagai petani sawah. Sedangkan objek penelitian ini adalah para pelaku UMKM sektor perdagangan dari jenis barang dagang pakaian jadi, sayuran, dan sembako.

Tabel 3. Rincian Data Responden

\begin{tabular}{|c|c|c|c|c|c|c|c|}
\hline \multirow[t]{2}{*}{ No } & \multirow{2}{*}{$\begin{array}{c}\text { Jenis Usaha Komoditas } \\
\text { Perdagangan }\end{array}$} & \multicolumn{2}{|c|}{ Sifat Usaha } & \multicolumn{2}{|c|}{ Ukuran Usaha } & \multicolumn{2}{|c|}{$\begin{array}{c}\text { Kepemilikan } \\
\text { NPWP }\end{array}$} \\
\hline & & Distributor & Eceran & Mikro & Kecil & Punya & Tidak \\
\hline 1 & Pakaian Jadi & 2 & 7 & 3 & 6 & 4 & 5 \\
\hline 2 & Sayuran & 5 & 2 & 0 & 7 & 2 & 5 \\
\hline \multirow[t]{3}{*}{3} & Sembako & 4 & 10 & 0 & 14 & 14 & 0 \\
\hline & Jumlah & 11 & 19 & 3 & 27 & 20 & 10 \\
\hline & Total & 30 & & & & & \\
\hline
\end{tabular}

Sumber: data primer, 2014 
Berdasarkan data lapangan, diperoleh hasil bahwa sebagian besar responden merupakan UMKM perdagangan sembako, pedagang eceran, pedagang skala kecil dan sudah memiliki NPWP.

\section{Penghitungan Pendapatan dan Biaya}

Dari hasil penelitian, ditemukan cara menghitung peredaran usaha dengan melihat kondisi pasar saat ramai dan sepi. Hal ini dilakukan untuk meminimalisir bias data.

Tabel 4. Trend Bulan Ramai dan Sepi Usaha

\begin{tabular}{lcc}
\hline Jenis Komoditas & Ramai & Sepi \\
\hline Pakaian & 2 bulan & 10 bulan \\
Sayuran & 11 bulan & 1 bulan \\
Sembako & 11 bulan & 1 bulan \\
\hline \multicolumn{2}{l}{ Sumber: data primer 2015} &
\end{tabular}

Kondisi di atas sesuai hasil wawancara masing-masing responden. Pedagang jenis komoditas pakaian mengalami masa ramai saat momen lebaran dan tahun baru, pedagang sayuran dan sembako mengalami masa sepi saat bulan Ramadhan. Jumlah bulan sepi dan ramai tersebut yang akan dijadikan dasar bagi estimasi rata-rata peredaran usaha responden.

Tabel 5. Data Peredaran Usaha dan Biaya UMKM Per Tahun (Juta Rupiah)

\begin{tabular}{|c|c|c|c|c|c|c|c|}
\hline \multirow{3}{*}{ Keterangan } & \multicolumn{6}{|c|}{ Jenis Komoditas } & \multirow{3}{*}{$\begin{array}{c}\text { Total } \\
\text { Responden }\end{array}$} \\
\hline & \multicolumn{2}{|c|}{ Pakaian Jadi } & \multicolumn{2}{|c|}{ Sayur } & \multicolumn{2}{|c|}{ Sembako } & \\
\hline & Distributor & Eceran & Distributor & Eceran & Distributor & Eceran & \\
\hline \multicolumn{8}{|c|}{ 1. Peredaran Bruto Setahun } \\
\hline Minimal & 290,25 & 105,00 & 258,75 & 262,50 & 350,00 & 345,00 & 105,00 \\
\hline Maksimal & 750,00 & 495,00 & 870,00 & 352,50 & $1.230,00$ & $1.040,00$ & $1.230,00$ \\
\hline Rata-rata & 520,00 & 260,00 & 671,25 & 307,50 & 730,00 & 621,30 & 518,34 \\
\hline Std. Deviasi & 325,27 & 145,31 & 242,45 & 63,63 & 366,24 & 247,70 & 112,19 \\
\hline \multicolumn{8}{|c|}{ 2. Biaya Usaha Setahun } \\
\hline Minimal & 253,80 & 75,60 & 149,40 & 191,10 & 236,50 & 151,20 & 75,60 \\
\hline Maksimal & 458,40 & 417,20 & 645,10 & 296,80 & 773,00 & 761,00 & 773,00 \\
\hline Rata-rata & 356,10 & 195,34 & 481,48 & 243,95 & 398,30 & 418,60 & 348,96 \\
\hline Std. Deviasi & 144,67 & 125,88 & 195,37 & 74,74 & 251,70 & 168,81 & 60.68 \\
\hline
\end{tabular}

Sumber: data primer diolah 2014

Tabel 5 menyajikan data peredaran usaha dan biaya dari 30 responden yang dibagi berdasarkan jenis komoditas dan sifat usaha. Peredaran usaha terendah ditemukan pada pedagang eceran pakaian jadi yaitu Rp105.000.000,00. Peredaran usaha terbesar ditemukan pada pedagang distributor sembako yaitu Rp1.230.000.000,00. Rata-rata peredaran usaha dalam penelitian yaitu Rp518.341.667,00. Biaya usaha yang terendah adalah Rp75.600.000,00 ditemukan pada pedagang eceran pakaian jadi. Biaya usaha tertinggi senilai Rp773.000.000,00 ditemukan pada pedagang distributor sembako. Rata-rata pengeluaran biaya usaha Rp348.962.143,00. 
Tabel 6. Data Nilai Pajak Terutang Per Tahun (Juta Rupiah)

\begin{tabular}{|c|c|c|c|c|c|c|c|}
\hline \multirow{3}{*}{ Keterangan } & \multicolumn{6}{|c|}{ Jenis Komoditas } & \multirow{3}{*}{$\begin{array}{l}\text { Total Respon- } \\
\text { den }\end{array}$} \\
\hline & \multicolumn{2}{|c|}{ Pakaian Jadi } & \multicolumn{2}{|c|}{ Sayur } & \multicolumn{2}{|c|}{ Sembako } & \\
\hline & Distributor & Eceran & Distributor & Eceran & Distributor & Eceran & \\
\hline \multicolumn{8}{|c|}{ 1. Metode Pembukuan } \\
\hline Minimal & 0,39 & 0,22 & 7,75 & 1,57 & 2,39 & 0,81 & 0,25 \\
\hline Maksimal & 35,81 & 7,67 & 32,18 & 2,05 & 77,30 & 57,27 & 77,30 \\
\hline Rata-rata & 18,10 & 2,35 & 19,27 & 1,81 & 50,94 & 23,58 & 19,34 \\
\hline Std. Deviasi & 25,04 & 2,47 & 8,81 & 0,34 & 35,38 & 21,67 & 13,91 \\
\hline \multicolumn{8}{|c|}{ 2. Metode Pencatatan } \\
\hline Minimal & 2,20 & 0,09 & 2,01 & 1,76 & 3,56 & 3,68 & 97,50 \\
\hline Maksimal & 18,87 & 4,50 & 23,98 & 4,57 & 39,78 & 29,14 & 39,78 \\
\hline Rata-rata & 10,54 & 1,77 & 16,17 & 3,16 & 18,85 & 13,80 & 10,71 \\
\hline Std. Deviasi & 11,78 & 1,82 & 8,54 & 1,98 & 15,17 & 9,22 & 5,32 \\
\hline \multicolumn{8}{|c|}{ 3. Metode PP No. 46 Tahun 2013} \\
\hline Minimal & 2,90 & 1,05 & 2,58 & 2,62 & 3,50 & 3,45 & 1,05 \\
\hline Maksimal & 7,50 & 4,95 & 8,70 & 2,52 & 12,30 & 10,40 & 12,30 \\
\hline Rata-rata & 5,20 & 2,60 & 6,71 & 3,07 & 7,30 & 6,21 & 5,18 \\
\hline Std. Deviasi & 3,24 & 1,45 & 2,42 & 0,63 & 3,66 & 2,47 & 1,12 \\
\hline
\end{tabular}

Sumber: data primer diolah 2014

Besarnya pajak terutang dengan nilai terendah menurut metode pembukuan ditemukan pada pedagang eceran pakaian jadi yaitu Rp255.000,00. Besar pajak terutang dengan nilai tertinggi pada pedagang distributor sembako yaitu Rp77.300.000,00. Rata-rata besarnya pajak terutang dari hasil perhitungan metode pembukuan Rp19.344.973,00.

Besarnya pajak terutang dengan nilai terendah menurut metode pencatatan ditemukan pada pedagang eceran pakaian jadi yaitu Rp97.500,00. Besarnya pajak terutang dengan nilai tertinggi ditemukan pada pedagang sembako distributor yaitu Rp39.787.500,00. Rata-rata besarnya pajak terutang dari hasil perhitungan metode pencatatan Rp10.717.530,00.

Besarnya pajak terutang dengan nilai terendah berdasarkan metode penghitungan PP No. 46 Tahun 2013 ditemukan pada pedagang pakaian jadi eceran yaitu Rp1.050.000,00. Besar pajak terutang dengan nilai tertinggi ditemukan pada pedagang sembako distributor yaitu Rp12.300.000,00. Rata-rata besarnya nilai pajak terutang dari hasil perhitungan metode PP No.46 Tahun 2013 sebesar Rp5.183.417,00. 
Tabel 7. Nilai Nominal dan Tarif Efektif Pajak Terutang

\begin{tabular}{|c|c|c|c|c|c|c|}
\hline $\begin{array}{l}\text { Metode Penghitungan } \\
\text { Pajak }\end{array}$ & \multicolumn{3}{|c|}{ Nilai Pajak Terutang } & \multicolumn{3}{|c|}{$\begin{array}{c}\text { Rasio Pajak Terutang terhadap } \\
\text { Peredaran Usaha }\end{array}$} \\
\hline \multicolumn{7}{|l|}{ 1. Sifat Usaha } \\
\hline & Distribut & & Eceran & Distributo & & Eceran \\
\hline Pembukuan & Terendal & & - & $4,60 \%$ & & $2,96 \%$ \\
\hline Pencatatan & - & & Гerendah & $2,42 \%$ & & $2,96 \%$ \\
\hline PP No. 46 & Tertingg & & ertinggi & $1,00 \%$ & & $1,00 \%$ \\
\hline \multicolumn{7}{|l|}{ 2. Jenis Komoditas } \\
\hline & Pakaian & Sayuran & Sembako & Pakaian & Sayuran & Sembako \\
\hline Pembukuan & - & Terendah & Terendah & $1,84 \%$ & $2,52 \%$ & $4,81 \%$ \\
\hline Pencatatan & Terendah & - & - & $1,17 \%$ & $2,20 \%$ & $2,34 \%$ \\
\hline PP No. 46 & Tertinggi & Tertinggi & Tertinggi & $1,00 \%$ & $1,00 \%$ & $1,00 \%$ \\
\hline \multicolumn{7}{|l|}{ 3. Ukuran Usaha } \\
\hline & Mikro & & Kecil & Mikro & & Kecil \\
\hline Pembukuan & - & & erendah & $0,99 \%$ & & $3,98 \%$ \\
\hline Pencatatan & Terendal & & - & $0,68 \%$ & & $2,53 \%$ \\
\hline PP No. 46 & Tertingg & & ertinggi & $1,00 \%$ & & $1,00 \%$ \\
\hline
\end{tabular}

Sumber: data primer diolah 2014

Tabel 7 memberikan informasi metode penghitungan pajak yang menghasilkan nilai nominal pajak terendah dan rasio pajak terhadap peredaran usaha (tarif efektif). Pada usaha perdagangan bersifat distributor, besarnya pajak terutang paling rendah ada pada metode pembukuan, dengan nilai Rp392.500,00 Usaha perdagangan bersifat eceran akan menghasilkan besarnya pajak terutang terendah pada metode pencatatan dengan nilai Rp97.500,00. Pada usaha berjenis komoditas pakaian, besarnya pajak terutang paling rendah ada pada metode pencatatan, dengan nilai Rp255.000,00. Usaha berjenis komoditas sayuran besarnya pajak terutang terendah pada metode pembukuan dengan nilai Rp1.570.000,00. Pada usaha berjenis komoditas sembako besarnya pajak terutang terendah pada metode pembukuan dengan nilai Rp817.500,00. Tabel di atas memberikan informasi nilai nominal pajak terutang terendah dan tertinggi berdasarkan ukuran usahanya. Pada usaha perdagangan berukuran mikro, besarnya pajak terutang paling rendah ada pada metode pencatatan, dengan nilai Rp97.500,00. Usaha perdagangan berukuran kecil akan menghasilkan besarnya pajak terutang terendah pada metode pembukuan dengan nilai Rp817.500,00.

Untuk menentukan metode perhitungan pajak terutang mana yang paling efisien bagi pelaku usaha, perlu dilakukan analisis tarif efektif atau rasio pajak terutang terhadap peredaran usaha. Tabel 7 menunjukkan prosentase perbandingan pajak terutang terhadap peredaran usaha, sesuai analisis sifat usaha, jenis komoditas, dan ukuran usaha. Pada usaha perdagangan bersifat distributor, perhitungan pajak dengan metode pembukuan menghasilkan rata-rata besarnya pajak terutang selama satu tahun berjalan adalah 4,60 persen dari peredaran usaha setahun. Perhitungan pajak dengan metode pembukuan pada usaha perdagangan bersifat eceran menghasilkan rata-rata besarnya pajak terutang selama satu tahun berjalan sebesar 2,96 persen dari peredaran usaha selama setahun. Perhitungan pajak dengan metode pencatatan pada usaha perdagangan bersifat distributor menghasilkan rata-rata besarnya pajak terutang selama satu tahun berjalan sebesar 2,42 persen dari peredaran usaha selama setahun. Sedangkan perhitungan 
pajak dengan metode pencatatan untuk usaha perdagangan bersifat eceran, menghasilkan ratarata besarnya prosentase pajak terutang selama satu tahun berjalan sebesar 2,96 persen dari peredaran usaha selama setahun.

Tabel 7 juga menunjukkan tarif efektif ketiga metode penghitungan pajak berdasarkan jenis komoditasnya. Usaha dagang berjenis komoditas pakaian jadi, perhitungan pajak dengan metode pembukuan menghasilkan rata-rata besarnya pajak terutang selama satu tahun berjalan adalah 1,84 persen dari peredaran usaha setahun. Perhitungan pajak dengan metode pembukuan pada usaha dagang berjenis komoditas sayuran menghasilkan rata-rata besarnya pajak terutang selama satu tahun berjalan sebesar 2,52 persen dari peredaran usaha selama setahun. Perhitungan pajak dengan metode pembukuan pada usaha dagang berjenis komoditas sembako menghasilkan rata-rata besarnya pajak terutang selama satu tahun berjalan sebesar 4,81 persen dari peredaran usaha selama setahun.

Perhitungan pajak dengan metode pencatatan pada usaha dagang berjenis komoditas pakaian jadi menghasilkan rata-rata besarnya pajak terutang selama satu tahun berjalan sebesar 1,17 persen dari peredaran usaha selama setahun. Perhitungan pajak dengan metode pencatatan untuk usaha dagang berjenis komoditas sayuran menghasilkan rata-rata besarnya prosentase pajak terutang selama satu tahun berjalan sebesar 2,20 persen dari peredaran usaha selama setahun. Usaha dagang berjenis komoditas sembako menghasilkan rata-rata besarnya prosentase pajak terutang selama satu tahun berjalan sebesar 2,34 persen dari peredaran usaha selama setahun.

Tabel 8. Perbandingan Marjin Laba Aktual pada Metode Pembukuan dan Norma Penghitungan Penghasilan Neto dengan Metode Pencatatan pada Usaha Sektor Perdagangan

\begin{tabular}{|c|c|c|c|c|}
\hline \multicolumn{2}{|c|}{ Keterangan } & Pembukuan & \multicolumn{2}{|c|}{ Pencatatan } \\
\hline \multicolumn{5}{|c|}{ Panel 1. Sifat Usaha } \\
\hline \multirow{2}{*}{\multicolumn{2}{|c|}{ Sifat Usaha }} & \multirow{2}{*}{ Marjin Laba } & \multicolumn{2}{|c|}{ Norma Penghitungan Penghasilan Neto } \\
\hline & & & Pakaian & Sembako \\
\hline \multirow{2}{*}{\multicolumn{2}{|c|}{ Distributor }} & $33 \%$ & $25 \%$ & $25 \%$ \\
\hline & Eceran & $30 \%$ & $30 \%$ & $30 \%$ \\
\hline \multicolumn{5}{|c|}{ Panel 2. Jenis Komoditas } \\
\hline \multirow{2}{*}{\multicolumn{2}{|c|}{ Jenis Komoditas }} & \multirow{2}{*}{ Marjin Laba } & \multicolumn{2}{|c|}{ Norma Penghitungan Penghasilan Neto } \\
\hline & & & Distributor & Eceran \\
\hline \multicolumn{2}{|c|}{ Pakaian } & $29 \%$ & $25 \%$ & $30 \%$ \\
\hline \multicolumn{2}{|c|}{ Sayuran } & $21 \%$ & $20 \%$ & $30 \%$ \\
\hline \multicolumn{2}{|c|}{ Sembako } & $33 \%$ & $25 \%$ & $30 \%$ \\
\hline \multicolumn{5}{|c|}{ Panel 3. Ukuran Usaha } \\
\hline \multirow[t]{2}{*}{ Kecil } & Rata-r & biaya & & $69 \%$ \\
\hline & Rata-r & in laba & & $31 \%$ \\
\hline \multirow[t]{4}{*}{ Mikro } & Rata-r & hasilan Bruto & & Rp203.035.714 \\
\hline & Rata-r & hasilan Neto & & Rp 55.142.857 \\
\hline & Rata-r & & & Rp 27.482.143 \\
\hline & Rata-r & Terutang & & $\operatorname{Rp} \quad 1.383 .036$ \\
\hline
\end{tabular}

Sumber: data olah 2014 
Perhitungan pajak terhutang dengan PP No. 46 Tahun 2013 menghasilkan rasio pajak terutang terhadap peredaran usaha (tarif efektif) paling kecil dibandingkan metode pembukuan maupun pencatatan, baik berdasarkan sifat usaha, jenis komoditas, maupun ukuran usaha. Hal ini disebabkan karena usaha perdagangan yang dijadikan responden penelitian ini memiliki marjin laba yang cukup tinggi yaitu 33 persen pada perdagangan distributor dan 30 persen pada usaha perdagangan eceran (lihat Tabel 8).

Apabila diasumsikan para wajib pajak dikenakan lapisan pertama tarif PPh Orang Pribadi sebesar 5\%, maka besarnya pajak terutang menurut metode pembukuan menghasilkan besar beban pajak yang lebih tinggi dibanding metode PP No 46 Tahun 2013. Pada perhitungan pajak terutang dengan metode pembukuan, maka kurang lebih besarnya pajak yang ditanggung usaha distributor adalah 1,65 persen $(5 \%$ x marjin laba sebesar $33 \%)$ dari peredaran usaha setahun. Adapun perdagangan usaha eceran menanggung 1,5 persen ( $5 \%$ x marjin laba $30 \%)$ dari peredaran usaha setahun.

Apabila dilakukan perhitungan pajak dengan metode pencatatan, usaha perdagangan distributor menanggung antara 1 persen sampai dengan 1,25 persen $(5 \%$ x norma penghitungan usaha jenis perdagangan distributor antara 20\% sampai $25 \%$ ) dari peredaran usaha setahun, sedangkan usaha perdagangan eceran menanggung 1,5 persen $(5 \% \mathrm{x}$ norma penghitungan usaha jenis perdagangan eceran 30\%). Perhitungan pajak terutang dengan metode PP No. 46 Tahun 2013, besar pajak yang ditanggung usaha perdagangan distributor maupun eceran adalah 1 persen dari peredaran usaha setahun (Tabel 8).

Perhitungan pajak terhutang dengan PP No. 46 Tahun 2013 menghasilkan rasio pajak terutang terhadap peredaran usaha paling kecil dibandingkan metode pembukuan maupun pencatatan, baik pada usaha dagang dengan jenis komoditas pakaian jadi, sayuran, dan sembako. Hal ini disebabkan karena usaha perdagangan yang dijadikan responden penelitian ini memiliki marjin laba yang cukup tinggi yaitu 29 persen pada usaha berjenis komoditas pakaian jadi, 21 persen pada usaha berjenis komoditas sayuran dan 33 persen pada usaha berjenis komoditas sembako.

Apabila diasumsikan para wajib pajak dikenakan lapisan pertama tarif PPh Orang Pribadi sebesar 5\%, maka besarnya pajak terutang menurut metode pembukuan menghasilkan besar beban pajak yang lebih tinggi dibanding metode PP No. 46 Tahun 2013. Pada perhitungan pajak terutang dengan metode pembukuan, maka kurang lebih besarnya pajak yang ditanggung usaha dagang berjenis komoditas pakaian jadi adalah 1,45 persen (5\% x marjin laba $29 \%)$ dari peredaran usaha setahun. Adapun usaha dagang berjenis komoditas sayuran menanggung 1,05 persen (5\% x marjin laba $21 \%$ ) dari peredaran usaha setahun. Usaha dagang berjenis komoditas sembako menanggung 1,65 persen (5\% x marjin laba 33\%).

Apabila dilakukan perhitungan pajak dengan metode pencatatan, usaha dagang berjenis komoditas pakaian jadi menanggung antara 1,25 persen sampai dengan 1,5 persen $(5 \% \mathrm{x}$ norma penghitungan usaha dagang berjenis komoditas pakaian jadi antara 25\% sampai 30\%) dari peredaran usaha setahun. Usaha dagang berjenis komoditas sayuran menanggung antara 1 persen sampai dengan 1,5 persen (5\% x norma penghitungan usaha dagang berjenis komoditas sayuran antara 20\% sampai 30\%) dari peredaran usaha setahun dan usaha dagang berjenis komoditas sembako menanggung antara 1,25 persen sampai dengan 1,5 persen $(5 \%$ x norma penghitungan usaha dagang berjenis komoditas sembako antara $25 \%$ sampai $30 \%$ ). Sedangkan untuk perhitungan pajak terutang dengan metode PP No 46 Tahun 2013, besar pajak yang ditanggung usaha dagang berdasarkan jenis komoditasnya (pakaian jadi, sayuran, dan sembako) adalah 1 persen dari peredaran usaha setahun. 
Untuk menentukan metode perhitungan pajak terutang mana yang paling efisien bagi pelaku usaha, perlu dilakukan analisis nilai rasio antara pajak terutang terhadap peredaran usaha, yang disajikan pada tabel di bawah ini.

Tabel 9. Perbandingan Rasio Pajak Terutang Terhadap Peredaran Usaha

\begin{tabular}{lcc}
\hline \multirow{2}{*}{ Metode Penghitungan Pajak } & \multicolumn{2}{c}{ Ukuran Usaha } \\
\cline { 2 - 3 } & Mikro & Kecil \\
\hline Pembukuan & $0,99 \%$ & $3,98 \%$ \\
Pencatatan & $0,68 \%$ & $2,53 \%$ \\
PP No 46 & $1,00 \%$ & $1,00 \%$ \\
\hline
\end{tabular}

Sumber : data olah 2014

Tabel 9 juga menunjukkan persentase perbandingan pajak terutang terhadap peredaran usaha, dengan ketiga metode penghitungan pajak berdasarkan ukuran usahanya. Pada usaha perdagangan berskala mikro, perhitungan pajak dengan metode pembukuan menghasilkan ratarata rasio pajak terutang selama satu tahun berjalan adalah 0,99 persen dari peredaran usaha setahun. Perhitungan pajak dengan metode pembukuan pada usaha perdagangan berukuran kecil menghasilkan rata-rata besarnya pajak terutang selama satu tahun berjalan sebesar 3,98 persen dari peredaran usaha selama setahun. Perhitungan pajak dengan metode pencatatan pada usaha perdagangan berukuran mikro menghasilkan rata-rata besarnya pajak terutang selama satu tahun berjalan sebesar 0,68 persen dari peredaran usaha selama setahun. Sedangkan perhitungan pajak dengan metode pencatatan untuk usaha perdagangan berukuran kecil, menghasilkan rata-rata besarnya prosentase pajak terutang selama satu tahun berjalan sebesar 2,53 persen dari peredaran usaha selama setahun. Perhitungan pajak dengan metode PP No. 46 Tahun 2013 untuk Usaha berukuran mikro dan kecil, menghasilkan rata-rata prosentase pajak terutang selama satu tahun berjalan sebesar 1,00 persen dari peredaran usaha selama setahun.

Perhitungan pajak terhutang dengan metode pencatatan menghasilkan rasio pajak terutang terhadap peredaran usaha paling kecil pada usaha berukuran mikro. Sedangkan perhitungan pajak terhutang dengan metode PP No. 46 Tahun 2013 menghasilkan rasio pajak terutang terhadap peredaran usaha paling kecil pada usaha berukuran kecil. Pada usaha berskala mikro, besarnya pajak terutang yang efektif menjadi beban pengusaha adalah 0,68 persen. Kondisi ini bisa terjadi karena nilai PTKP yang menjadi pengurang PKP bernilai relatif material pada usaha mikro, sehingga adanya PTKP dapat menurunkan pajak terutang sampai dibawah 1 persen. Tabel di atas juga menggambarkan bahwa rata-rata PTKP pada usaha berskala mikro hampir mencapai 50 persen dari penghasilan bersihnya, sehingga dengan adanya PTKP ini akan menyebabkan pengurangan yang cukup material pada jumlah pajak terutang.

Adapun pada usaha berukuran kecil, perhitungan pajak terhutang dengan PP No. 46 Tahun 2013 menghasilkan rasio pajak terutang terhadap peredaran usaha paling kecil dibandingkan metode pembukuan maupun pencatatan. Hal ini disebabkan karena usaha perdagangan berukuran kecil yang dijadikan responden penelitian ini memiliki marjin laba yang cukup tinggi yaitu 31 persen. Apabila diasumsikan para wajib pajak dikenakan lapisan pertama tarif PPh Orang Pribadi sebesar 5\%, maka besarnya pajak terutang menurut metode pembukuan menghasilkan besar beban pajak yang lebih tinggi dibanding metode PP No. 46 Tahun 2013. Pada perhitungan pajak terutang dengan metode pembukuan, maka kurang lebih besarnya pajak yang ditanggung usaha kecil adalah 1,55 persen (5\% x marjin laba sebesar $31 \%$ ) dari peredaran usaha setahun. 


\section{SIMPULAN DAN SARAN}

Sesuai hasil penelitian, penghitungan pajak dengan Metode PP No. 46 tahun 2013 akan menghasilkan prosentase pajak terutang paling efisien untuk usaha dagang baik bersifat distributor maupun eceran, berjenis komoditas pakaian jadi, sayuran dan sembako serta usaha dagang berukuran kecil, sedangkan penghitungan pajak metode pencatatan akan menghasilkan prosentase pajak terutang paling efisien pada usaha berukuran mikro.

Implikasi temuan penelitian ini dapat memberikan masukan bagi Pemerintah agar perlu mempertimbangkan syarat keharusan penggunaan penghitungan pajak dengan metode PP No. 46 Tahun 2013 bagi wajib pajak tertentu, namun pemberlakuan metode perhitungan pajak tersebut lebih merupakan pilihan atau opsional (antara pembukuan dan pencatatan menurut UU PPh No. 36 tahun 2008 atau PP No. 46 tahun 2013). Apabila jiwa dari pemberlakuan PP No. 46 Tahun 2013 adalah untuk kesederhanaan dan kemudahan bagi wajib pajak, maka akan baik jika pemerintah memberikan pilihan bebas bagi wajib pajak terkait metode apakah yang akan dipakai (menurut UU No 36 Tahun 2008 atau PP No 46 Tahun 2013). Pemberian pilihan bebas ini akan memberikan insentif bagi wajib pajak, terutama pada kelompok yang dirugikan oleh penerapan PP No. 46 Tahun 2013.

Berdasarkan hasil penelitian, untuk kelompok responden usaha perdagangan berukuran mikro, PP No. 46 Tahun 2013 bukan metode penghitungan pajak yang menghasilkan pajak efisien karena apabila mereka diperkenankan memilih dan mampu untuk melaksanakan pencatatan, maka beban pajak mereka akan lebih kecil. Dari sudut pandang pemerintah perlu dievaluasi dan dipertimbangkan penerapan metode perhitungan pajak penghasilan khususnya terkait penerapan PP No. 46 Tahun 2013 tidak bersifat wajib melainkan bersifat opsional (dapat tetap memilih perhitungan pajak penghasilan menurut UU no 36 tahun 2008).

Hasil penelitian ini menganalisis metode penghitungan pajak dari prinsip efisiensi. Padahal pada dasarnya pembentukan Peraturan Pemerintah No. 46 Tahun 2013 bertujuan memberi kemudahan kepada para wajib pajak terhadap kewajiban perpajakannya. Dengan adanya kemudahan tersebut, diharapkan kesadaran dan kepatuhan wajib pajak untuk memenuhi kewajibannya semakin meningkat. Oleh karena itu di masa yang akan datang diharapkan dapat dilakukan penelitian tentang kesadaran, minat, dan kepatuhan wajib pajak terhadap kewajiban perpajakannya pasca terbentuknya PP No. 46 Tahun 2013.

\section{REFERENSI}

Adhitama, Satria. 2013. Pajak Penghasilan pada Para Pelaku Usaha Konveksi di Kecamatan Tingkir Kota Salatiga. Skripsi. Fakultas Ekonomika dan Bisnis Universitas Kristen Satya Wacana. Salatiga.

Arum, Harjanti P. 2012. Pengaruh Kesadaran Wajib Pajak, Pelayanan Fiskus, dan Sanksi Pajak terhadap Kepatuhan Wajib Pajak Orang Pribadi yang Melakukan Kegiatan Usaha dan Pekerjaan Bebas. Skripsi. Fakultas Ekonomi Universitas Diponegoro. Semarang

Badan Pusat Statistik Perdagangan Kabupaten Semarang. 2012. Diakses 20-Aug-2014. http:// semarangkab.bps.go.id/index.php?hal=tabel\&id=23

Barata, Adya. 2011. Panduan Lengkap Pajak Penghasilan. Jakarta: Visimedia. 
Berita Online "Harian Bisnis Indonesia". 30 Juli 2012. Artikel berjudul "Tingkat Kepatuhan Wajib Pajak Rendah". Diakses tanggal 10 Agustus 2014. http://www.ortax.org/ ortax $/$ ?mod=berita\&page $=$ show $\& \mathrm{id}=12450 \& \mathrm{q}=\& \mathrm{hl} \mathrm{m}=6$

Bisnis.com. 2014. Potensi Penerimaan Pajak UMKM Baru 7\%. Diakses 9 Maret 2016 dari http://finansial.bisnis.com/read/20141026/10/267913/potensi-penerimaan-pajakumkm -baru-7

Choiruman, A. (2004). Pemeriksaan Pajak Masa Depan. Diakses tanggal 20 Agustus 2014. http://www.indodigest.com/indonesia-specialthoughts-106.html

Herman, R. And H, Nurul. 2013. Peranan UMKM dalam Pembangunan Ekonomi Indonesia Melalui Pajak. Fakultas Ekonomi dan Bisnis Universitas Mercu Buana. Jakarta.

Jacklyn, Eunike S, dan Sirajuddin, Betri. 2013. Pemahaman Wajib Pajak Terhadap Peraturan Pemerintah Nomor 46 Tahun 2013 Tentang Pajak UKM. Skripsi. Universitas Bina Darma. Palembang

Jackson, B. R. dan V. C. Milliron. 1986. Tax compliance research: Findings, problems and prospects. Journal of Accounting Literature, Issue 5.

Komoditi Produk Jenis Usaha (KPJU) Unggulan Lintas Sektorat Tingkat Kabupaten di Provinsi Jawa Tengah. Diakses tanggal 6 Agustus 2014. http://www.bi.go.id/ id/umkm/ kelayakan/komoditi/Default.aspx?Prov=Jawa\%20Tengah

Kurniawan, Richard. 2004. Sadar Pajak, Kunci Pembangunan. Fakultas Ilmu Sosial dan Ilmu Politik. Universitas Indonesia. Jakarta

Laporan Studi Potensi Perusahaan Usaha Mikro Kecil Menengah untuk Go Public. 2011. Diakses tanggal 27 Agustus 2014. http://www.bapepam.go.id/pasar_modal/publikasi_pm/ kajian_pm/studi-2011/potensi-ukm-go-public

Pajak.go.id. 2013. Penyederhanaan Aturan Pajak dalam Peraturan Pemerintah Nomor 46 Tahun 2013. Diakses tanggal 10 Agustus 2014. http://www.pajak.go.id/content /news/ penyederhanaan-aturan-pajak-dalam-peraturan-pemerintah-nomor-46-tahun-2013

Peraturan Pemerintah Republik Indonesia Tahun 2013 Nomor 46 tentang Pajak Penghasilan atas Penghasilan dari Usaha yang Diterima atau Diperoleh Wajib Pajak yang Memiliki Peredaran Bruto Tertentu.

Peraturan daerah kabupaten Semarang No. 6 Tahun 2011 tentang Rencana Tata Ruang Wilayah Kabupaten Semarang 2011-2031.

Prasetyono, Sunar. 2011. Panduan Lengkap Tata Cara Perhitungan Pajak Penghasilan dan Petunjuk Pengisian SPT. Jakarta: Laksana.

Pudjono, A. N. S. 2014. Meningkatkan Rasio Kepatuhan Pajak di Indonesia. Diakses dari pajak. go.id 8 Maret 2016.

Resyniar, Gandhys. 2013. Persepsi Pelaku Usaha Mikro kecil Menengah Terhadap Penerapan PP. 46 Tahun 2013. Jurnal Ilmiah Mahasiswa. Universitas Brawijaya.

Rustiyaningsih, Sri. 2011. Faktor-faktor yang mempengaruhi kepatuhan wajib pajak. Jurnal Widya Warta No. 002. Fakultas Ekonomi Universitas Katolik Widya Mandala. Madiun. 
Surat Keputusan Dirjen Pajak Nomor KEP-536/PJ/2000 tentang Norma Penghitungan Penghasilan Neto Bagi Wajib Pajak Yang Menghitung Penghasilan Neto Dengan Norma Penghitungan.

Undang-Undang Nomor 36 Tahun 2008 tentang Perubahan Keempat atas Undang-Undang Nomor 17 Tahun 2000 Tentang Pajak Penghasilan. Jakarta: PT Cipta Bina Parama.

Undang-Undang Nomor 20 Tahun 2008 mengenai Usaha Mikro Kecil, dan Menengah.

Waluyo. 2012. Akuntansi Pajak (ed.1). Jakarta: Penerbit Salemba.

Wirapati, I. P. W dan I. K. Jati 2014. Faktor-Faktor yang Memengaruhi Kepatuhan Pengrajin Dalam Memiliki NPWP di Kabupaten Gianyar, E-Journal Akuntansi Universitas Udayana, diakses dari http://ojs.unud.ac.id. 